UNIVERSITY OF CHITRAL JOURNAL OF LINGUISTICS AND LITERATURE

VOL. 3 | ISSUE I | JAN - JUNE | 2019

ISSN (E): 2663-1512, ISSN (P): 2617-3611

\title{
Determination of Socio-economic Conditions through Wealth and Material Possessions: A Marxist Critique of Mansfield's Doll's House
}

\author{
Sidra Ahmad \\ Foundation University, Islamabad, Pakistan
}

\begin{abstract}
The current paper talks about the unavoidable class system that we all are entrapped in. The basic issue lies in the fact that the society we live in and grow operates on the system of class consciousness. The rich /bourgeoisie class uses and abuses the low or poor class to get their work done, whereas the poor or the proletariat has no choice except to be manipulated by the rich class for the cost of labor, for they know that their survival lies in manipulation. It has become an accepted phenomenon that the rich class/bourgeoisie exploits the poor class for their needs and desires. The rich class has become totally dependent on the proletariat and they know they cannot move without them. As the society is designed and planned on unequal footings so, on the one hand, the rich class has found a medium to exploit the labor class but at the same time the proletariat are not allowed to interact with them and furthermore there is bleak chance of their unification as the lower/labor class is itself a stigma in the eyes of the bourgeoisie.
\end{abstract}

Keywords: Bourgeoisie, Proletariat, economic power, commodification, superstructure, ideology, class consciousness, dialectical and historical materialism.

\section{Introduction}

Karl Marx is attributed to the formulation of his revolutionary theory which is termed as Marxism. Marx was interested in knowing that how human beings are shaped and how relationships in the society formed. He was not interested in solving the problems of the people at the individual level rather focused on economic production and thought. According to Barry (1995), "The aim of Marxism is to bring about a classless society, based on the common ownership of the means of production, distribution, and exchange" (p. 106). Karl Marx is of the notion that the state has some binding on the proletariat that they cannot own the land or make property as it is the possession of the state which initiates class struggle or class consciousness. One class is getting maximum benefits and enjoying all the facilities of life and is getting richer day by day while the other class is deprived of all the basic needs and have to face continuous exploitation of their bosses. As quoted by Barry (1995) "Marxism sees progress coming about through the struggle for power between different social classes" (p. 108).

\section{Statement of the problem}

It has become the order of the day to exploit the proletariat and attain maximum benefits from them as they belonged to the suppressed strata of society. The working class is bound to obey their 
bosses because they know that they have no other option than to be exploited as both bourgeoisie and proletariat are one at the same time dependent on each other. The rich, because they want to get their work done at any cost and proletariat because of the charm of the money which is their sole need and desire to fulfill their requirements are in the continuous struggle mode but both of the antagonistic forces cannot get along with each other as their interests are opposite.

\section{Literature Review}

\section{Dr. L.Amutha}

Dr.L.Amutha in the article "Class Consciousness with reference to Katherine Mansfield's The Doll's House" has talked about the class consciousness which complicates and upsets the balance of society. According to Amutha the class in which a person is born becomes his permanent identity and it gets really difficult for him to maintain his social prestige in society if he is born to a lower class. The malpractices become evident from the character of Aunt Beryl as she contemplates the Kelvey sisters not fit for sighting the dazzling and attractive things in life as they are the daughters of a washerwoman and a jailbird so they are subject to hatred and victimization. As Amutha (2018) portrays the behavior of Aunt Beryl by writing "Her behavior clearly expressed that she viewed the Kelvey sisters as poor and unworthy of viewing something as beautiful and expensive as the doll's house" (p.14).

\section{Sahin Kiziltas}

Sahin Kiziltas while writing about The Review of The Doll's House by Katherine Mansfield through the Philosophy of Louis Pierre Althusser states that it is only the prerogative of the governing body to construct boundaries around the better sort and the excluded ones by means of ideological apparatuses. Kiziltas (2014) quoted Althusser and states that “ ... an ideology always exists in an apparatus and its practice or practices. This existence is material" (p.128). The elites set the roles for the working class and they are not allowed to break, reshape and navigate the roles. The ultimate destination of the working class is to remain there where they are since ages because their identity is fixed and they cannot climb the corporate ladder because of the social structures and the stereotyping of the society towards them. The so-called high gentry of the society does not absorb the fact that the member of a working-class can have beautiful articles/ items and is in the same position as that of the elites. They deny the working class the right of intermingling with the rich class as has been witnessed and that because of established ideologies. Aunt Beryl banned the Kelveys from communicating with the Burnell's and restrict them to enter their house and on the other hand the mother of Kelveys forbade them to fuse and get along with the Burnells as she is very much well aware of her boundaries which exerts a negative impact on the personalities of the Kelveys making them alienated, shaky and fearful from society. Kiziltas tried to establish the fact that due to the undue and unreasonable burden and stress exerted on the working class by the elites, the working class is bound to follow the philosophy of the governing bodies. Kilitaz stated that "The society takes the shape through the goals of the class" (136). 


\section{Altinay Ozen}

Altinay Ozan in his article "Althusser's Ideological state apparatuses and literary criticism" suggests that ideological state apparatus functions simultaneously with the repressive state apparatus. As Ozan states about Althusser that for him, people are the by-product and commodity with no harmony and identity of their own. Talking about Karl Marx, Altinay is of the view that for Marx the poor class is determined by the bourgeoisie. Ozen quoted Althusser (1970) and writes in Ideological State Apparatuses and Literary criticism that "superstructure is determined by the base" (p.1). For Althusser, there are other factors besides superstructure and base and he gave the term "interpellation" for it. Ozen while reviewing Althusser's perspective commented that every human /person is not a commodity but possesses their own individuality and existence.

\section{Methodology}

The research would be a qualitative one. The text of the Doll's House will be explored for content, themes and context. It will be carried out with the help of books and material available on the internet. Marxism would be the model of study.

\section{Purpose of work}

The paper is written to highlight the most pertinent fact that domination and dictatorship of the capitalist lead to the conflict between the two opposing forces.

\section{Gap/ contribution of work}

Many researchers have explored ideology, class consciousness and ideological apparatus, I will be analyzing The Doll's House from the perspective of material possession in totality and loopholes in the economic system as viewed by Marx.

\section{Objectives}

The main objective is:

1. To determine whether the bond of unification exists between the bourgeoisie and the proletariat.

\section{Research Question}

1. Can the bond of unification exist between the proletariat and bourgeoisie?

\section{Analysis}

It is true that the class struggle has been observed since time immemorial. The story The Doll's House seems to be the reflection of Mansfield's own life. Barry (1995) found "A writer's social class and its prevailing ideology (outlook, values, tacit, assumptions, half-realized allegiances, etc.) have a major bearing on what is written by a member of that class (p. 107). She was born to a middle-class family at the time when the class distinction was common and had a closer glimpse of that aura. Dobie (2012) commented, "Named for the assumption that a text will reflect the society that has produced it" (p. 80). The story seems to be the depiction of the writer's age and her social status. Barry (1995) opinionated "Every facet of a writer is linked to some aspect of her 
or his social class" (p.108). Mansfield has undergone the same circumstances as her characters have witnessed, so she used imagination to escape the harsh realities of that time. The writer usually uses imagination because they are alienated and feel alienated and want to translate their dreams because their dreams were never fulfilled. Barry (1995) beautifully explained such phenomenon by writing, "To Tennyson the Keatsian world of romance, to Browning the Italian springtime; both are revolting backward, trying to escape from the contradiction of the class for whom they speak" (p.105).

Society is a social construct that can be shaped and reshaped by humans. Nagarajan (2006) quoted "Society is not a vague, indistinct background" (p.224). The Doll's House, reflect the clear-cut division of two classes' i-e between bourgeois and proletariat. The society that is depicted in the text is the capitalist society and consequently, all the bounties are for them. The text informs us about the children of two classes, Burnells and Kelveys. The Burnells are the children of the upper class while the Kelveys belonged to the lower strata of society and truly conveys the idea that the superstructures are the parasite on base. They do the work for the elite class but still denied the basic needs and rights which is the structured view of reality.

The Burnell girls because they belonged to the upper class and due to their social status are proud, show off and cruel. They are used to of the elegant life-style and fond of glamorous items. The "Doll's House" which is presented by Mrs. Hay to the Burnell girls is the depiction of their social circle and their stylish lifestyle. Mansfield (2012) shares even the slightest of the details regarding the doll's house and writes, "There stood the doll's house, a dark, oily, spinach green, picked out with bright yellow. It's two solid little chimneys glued on the roof, were painted red and white, and the door, gleaming with yellow varnish, was like a little slab of toffee" (p.135).

It is rightly said that powerful people are occupying the sources of the universe. Karl Marx gave importance to the socio-economic class. As Tyson (2006) found "Marxists analysis of human events and productions focus on relationships among socioeconomic classes, both within a society and among societies, and explain all human activities in terms of the distribution and dynamics of economic power" (p. 54). The bourgeoisie can buy everything because of their wealth and richness and do whatever they want to do. The philosophy of who you are and what is your social standing or status in the world is pertinent here. As the upper class is privileged and can afford to buy things that the other people or the poor people cannot even dream of. Their gifts are so gaudy and expensive which is depicted in the story, where the doll's house is opened and the children were amazed to see the beauty of the doll's house. Mansfield (2012) quoted "All the rooms were prepared. There were pictures on the walls, painted on the paper, with gold frames complete. Red carpet covered all the floors except the kitchen" (p. 136).

The story can be aptly rated as the story of the capitalistic society where the cruelties of the upper class are exposed. The Burnells are believed to be active, superior, cultured, sensible and energetic while the Kelveys are believed to be strange, dirty, lazy, uncultured and backward. In-short the Kelveys were considered to be inferior or othered because they belonged to the working class. A 
rigid sort of class distinction is seen where the working class is seen suffering because of their weak status. As Mary Shelly pointed out in Frankenstein the attitude of the rich class and aptly described them as monsters. As the law of living requires and demands that if you want to interact with people, you need to be belonging to the same class, otherwise you will be rejected. The same situation is faced by Kelveys as they belonged to the lower class and could not have those attractions or the socioeconomic conditions which the Burnells enjoy so they were rejected and out-casted by everybody. Nagarajan (2006) highlights "People are divided primarily by their differences in socioeconomic conditions" (p. 225). It is the requirement of surviving in the world full of the bourgeoisie, that if you want to compete with somebody, you need to be in the same position. As the Kelveys were living below the poverty line so they were bound to suffer and faced isolation in the school from everyone. Mansfield (2012) highlights the situation of Kelveys by saying, "And the only two who stayed outside the ring were the two who were always outside, the little Kelveys (p. 137).

The text indicates that power is based on wealth and material possessions. People in society are attracted to wealth and material possessions. The wealthier or rich a person is, the more respect, he has in society. People are impressed by outward appearances. If somebody has wealth and enjoying the facilities of life, then he thinks that he is superior and undermines others. Burnells are enjoying such power because they have been given a big doll's house. It's the doll's house that makes the Burnell girls powerful and raises their economic conditions. Nagarajan (2006) quoted "Economic power is behind all institutions" (p.223). The doll's house has become a reason for domination by the Burnell girls. The house is responsible for creating the gap between the rich and the poor which can never be abridged. By showing the doll's house to other students or to other girls in their social circle, they can boast about their class and wealth in front of the people. Dobie (2012) states "Those who control production have a power base; they have many ways to ensure that they will maintain their position" (p.82). As economy functions as a base which can be observed where the Burnell children could not resist telling others about their doll's house. Mansfield (2012) found "They burned to tell everybody, to describe, to...well...to boast about their doll's house before the school bell rang" (p. 136).

The commodification of things is observed, as Marx is of the view that it's the attitude of things not for the purpose of utilizing but to impress others. The Burnell girls are a victim of society's emphasis on significant value. They were always in a race to impress the people belonging to their class. They do this in order to be get noticed by the people and to remain in limelight. The Burnell girls want to boast about their economic and social standing in front of the other girls. They had to follow the norms of society in order to exist in that social set up. The Doll's House is the medium to show off their wealth and ownership. They cannot live without doing this. The phrase "The girls of her class" is used by Mansfield to highlight that the Burnells really belonged to the high social order. The Doll's house was the focal point of all eyes. Seldon, Widdowson, and Brooker (2005) 
pointed out "Human history will in some sense determine the whole cultural life of the society" (p.83).

A sort of double marginalization is observed in the text. First of all, the Kelveys are poor and secondly, they belonged to the lower strata of society so they are alienated from society which shows the unjust ways of the world and society. As the Burnells belonged to the upper class so they think that everything is made for them. They can enjoy all the luxuries because they are only made for them. The Burnells are of the opinion that as they are born in the privileged class, so they deserved the best of everything and the Kelveys because of their social status or position deserved to be outlawed and have no ownership of anything. They will be controlled by the rich class. According to Karl Marx, it's the elite or the upper class that has become usurpers and blackmailers. The upper class in the text have their own circle and shell and they only liked to interact with the girls who are from the capitalist background as that of them. They do not like to intermingle with the lower class as they are forbidden and eventually, Mansfield (2012) noticed that state and portrays in her short story as "The line had to be drawn somewhere. It was drawn at the Kelveys (p. 137). According to Marx, it is not fate but the economic conditions that has played a part to make them helpless, powerless and defenseless to enjoy the status as the Burnell's were enjoying. Reading of the story indicates pride and prejudiced against the lower class. The Burnells took pride in belonging to the upper class and owning a doll's house. They are prejudiced towards Kelveys as they do not belong to the same class. Seldon, Widdowson, and Brooker (2005) opined in the book "The material interest of the dominated social class determines how people see human existence, individual and collective" (p.62). From the text it can be easily noticed that the Kelveys are misrepresented. They are believed to be the tabooed subject by everyone. They were thought of uncultured, spoilt and ill-mannered.

It is true that the tools of production determine value. As written by Dobie (2012) "The moving force behind human history is its economic systems, for people's lives, are determined by their economic circumstances (p.82). We can see in the story that the proletariat is repressed and oppressed by everyone. Although these proletariat work for the bourgeoisie still they have to bear the contempt of the elites. This bourgeoisie is dependent on proletariats and have their own material gains or benefits. They are forced to work for the bourgeoisie but still are hated by the elites and treated as if they are not acceptable in society. Dobie (2012) commented, "As they take on less attractive jobs to pay back what is owed, they are even less acceptable in the corridors of wealth and power" (p.84).

The Marxist critics noticed some serious loopholes in the economic system. A harsh reality is observed which is quoted by Mansfield (2012) in her short story as "The truth was that they were dressed "in bits" given to her by the people for whom she worked" (p.137). The Kelveys were bound to wear the tits or bits given to them by the people. The problem is that there is a socioeconomic gulf between haves and have-nots that can never be abridged which proves Nagarajan's (2006) concept of class struggle which he has highlighted "History is a class struggle" 
(p.225). The Kelveys belonging to the proletariat were stereotyped and had to face severe criticism from the elites and were badly tortured. They were given the lesson by the bourgeoisie that they deserved to be oppressed and suppressed and had to face the inequalities created by the capitalists. They were believed to be insignificant or mere dots having no value. As Lena targets the Burnells which Mansfield (2012) quoted "Is it true you're going to be a servant when you grow up, Lil Kelvey" (p.138). The bourgeoisie thinks that as their parents have done manual labor, the next generation would do the same which depicts that they in a way are snatching their rights to progress. Dialectical materialism comes to play here and according to which people's actions and reactions are the results of the materialist society, they live in. Dobie (2012) writes, "An imbalance of goods and power among people or manipulation of the worker by the bourgeoisie and will point out the injustice of that society" (p.87). The working class is controlled by the elites. They are used and misused by the people in their own ways with the result that the outcome of it leads to the naming of the working class as the commodity for the bourgeoisie. As Barry (1995) explains "People become things" (p.105). The proletariats have to suffer at each and every step and are exploited by the upper class badly which results in alienation. They are alienated from society and the elites are usurping their chances of survival. The circulation of money and hold of power remain in the hands of one class which leads to classism and alienation in society. As the Kelvey girls belonged to the working class, they were considered to be inferior and given a shut-up call by everybody. Mansfield (2012) quoted their situation as "The Kelveys were shunned by everybody" (p.139)." Their economic conditions differentiate and forced them to disconnect with society and suffer for nothing. Tyson (2006) writes, "The majority of the global population who lived in substandard conditions and have always performed manual labor" (p.54). Had the Kelvey sisters been enjoying the luxurious items and have no disgracing marks like that of incompatible economic conditions, they would definitely be in a better position which means that it is the game of socio-economic conditions. The more sound and financially stable you are and can afford material possession, the more respectable and honorable you become in the eyes of people.

The society depicted in the text has taken all the chances and opportunities from the proletariats which resulted in their sufferings. The goods and the wealth are unevenly distributed between two strata of society which is a negative consequence and results in repression of many. Aunt Beryl gets annoyed when Kezia tried to abridge the gulf between the rich and the poor. Aunt Beryl could not stand this and seems to be burning with anger. Mansfield (2012) quoted the situation "You are not allowed to talk to them" and "She stepped into the yard and shooed them out as if they were chickens" (p.142). The bitter comments of Aunt Beryl are enough to identify the type of society in which they were living where cruelty and snobbery are regarded as acceptable behavior. As quoted by Selden, Widdowson, and Brooker (2005) "The proletariat and the working class are always subjugated by the bourgeoisie. The rich control the resources, and the wealth of a nation" (p.225). 
The ideology presented in society is that of powerful people. The exploitation of the upper class leads to the formation of ideologies in society. According to Marxist critics like Selden, Widdowson and Brooker (2005) found "Ideology in Marxism means a system of beliefs using which human beings make sense of the world they live in" (p. 225). The text seems to be glamorizing the powerful people to show their standing and place in society. The working class is strictly controlled by the bourgeoisie, giving them the message that they are not free in any case. The text supports the values of capitalism that the cruel controlling class or bourgeoisie is always there to rule over them. The Kelveys were the scapegoat of the class distinction. They are described with animal images at every stage. They were not allowed to live in the society in a respectable way with their heads high rather had to face public humiliation by the elites. Dobie (2012) commented, "An ideology, dictated by the dominant class, functions to secure its power" (p.86). They were called by animal images. Our Else was called little white owl which reflects the social behavior of people and in a way, it also denotes that they are not welcomed in their social scale. There are occasional associations when the animals are connected with the two Kelveys. Once "Else" is compared with little "white owl" and another time, both are said to be "little two stray cats" and Aunt Beryl treats, "Those little cats as if they were chickens" (Mansfield,2012, p. 139). The Doll's House represents the ideology of the bourgeoisie that the working class deserves the luxurious items and the proletariats deserved to be oppressed. Such a society is unfair and uncaring. As Marx is of the opinion that powerful people keep their positions in society and try to suppress and oppress the working class and believed that they deserved oppression. The inside view of the Doll's House determines that it is not at all to be used by the proletariats, rather the rich (The Burnells) should have them because it matches their personalities. Nagarajan (2006) explains, "life is not determined by consciousness but consciousness by life" (p.223).

It is true that society has the potential to be treated equally and unified, though at the start of the story we could see that the Doll's house was freshly painted and giving a smell. The child narrator says, "And perhaps the smell of paint could have gone off by the time it had to be taken in" and the smell of the paint was quite enough to make anyone seriously ill. The smell of the paint basically reflects the sting or the hatred of the bourgeoisie towards the proletariat. It also determines that the bourgeoisie are a misfit in society that's why they had to suffer alienation at the hands of modern society and don't deserve to be happy. As Nagarajan (2006) explains "The personality of man is represented as disintegrated; he is shown to be solitary, asocial, and unable or unwillingly to enter into a happy communion with fellow human beings" (p.227).

It's the lamp and Kezia that tries to shake off all the inequalities. The lamp being a particular item brought meaning to the story because due to the historic background these lamps were manufactured by hardworking laborers and are purchased by wealthy, so the lamp represents the division between the classes even though its beauty is appreciated no matter what social class you belonged. Its picturization has been sketched beautifully by Mansfield (2012) where she captured Kezia's reaction by saying, "You've forgotten the lamp" and "the lamp's best of all" (p.96). These 
lamps serve as the sacrificial lights at the altar of the wealthy capitalist. According to Marx, these working proletariats are individuals who sell their labor power for wages and who do not own the means of production and argues that they were responsible for creating the wealth of society but ironically treated with contempt and disdain by society. The remark of "Our Else" at the end "I seen the little lamp" (Mansfield,2012, p. 143). When the others kept reminding her of class status, Kezia insists on her thought of equality to the prejudiced views of the members of her social class and by doing so she is trying to break the social hierarchy of class inequalities. The innocent world of a child who does not really understand the reasons and the deeper social meaning of all this stand opposite the rule-governed the world of the adults. The lamp becomes the harbinger between Kezia and Our Else. The lamp is the ray of hope between two classes so that they can be treated on equal grounds. The girls admired and appreciated the innocent lamp which put both of them in the same situation and similar status which is a direct hint or a hit on society that how it is unbalanced and dissimilar but it does have the unifying power and characteristics. It is a social leveler. As quoted by Nagarajan (2006) "The power structures can only be altered by the coming together of the proletariat, forgetting its division" (p.225).

\section{Conclusion}

Kezia says at the end of the story, "You can come and see our doll's house if you want to," and Lil answered, "Your ma told our ma you wasn't to speak to us." It reflects social distinctions and depicted where Kelveys because of their social status are not allowed to talk to the higher class or Burnells. They knew better than to come anywhere near the Burnells" (Mansfield, 2012, p. 137). It is the ideology that promotes false consciousness. From the story, Mansfield tried to established that power is based on wealth and material possessions. Society has the power to be unified but the bourgeoisie never liked this to happen because if there is a concept of classless society then both will be judged on equal grounds and this is not possible.

\section{References}

Amutha.L.(2018). Class Consciousness with reference to Mansfield's Doll's House. Language in India, 18:3, 12-17

Barry, Peter. (1995). Beginning Theory: An Introduction to Literary and Cultural Theory ( $2^{\text {nd }}$ ed.). Manchester, Uk: University Press

Bowens, Tyneisha.,Caroll, Ben., Dowell, Leilani., Everett, Elena., Fry, Julie.,... Strobino, Dante. (1974). What is Marxism all about. New York: Worldview Forum

Dobiee, Ann. (2015). Theory into Practice: An Introduction to Literary Criticism (3 ${ }^{\text {rd }}$ ed.). Stanford, CT: Cengage Learning

Gaunce, Julia., Mayr, Suzette., Lepan, Don., Mather, Majorie and Miller, Bryanne. (2012). The Broad view Anthology of short Fiction (2 ${ }^{\text {nd }}$ ed.). Canada: Broadview Press 
UNIVERSITY OF CHITRAL JOURNAL OF LINGUISTICS AND LITERATURE

Kiziltaz, Sahin. (2014). The Review of the doll's House' by Katherine Mansfield Through the philosophy of Louis Althusser. Ataturk Universitiesi Sosyal Bilimler Engitusu Dergisi,18(2): 127-137

Lois, Tyson. (2006). Critical Theory Today: A User-Friendly Guide (2 ${ }^{\text {nd }}$ ed.). New York, London: Routledge

Nagarajan, MS. (2006). English Literary Criticism and Theory: An Introductory History. India: Longman Press

Ozen, Altinay. (1971). Althusser Ideological State Apparatuses Literary Criticism. London: 121131

Selden, Widdowson, and Brooker (2005). A Reader's Guide to Contemporary Literary Theory $\left(5^{\text {th }}\right.$ ed.). Great Britain, Uk: Longman Press

Shelly, Marry. (1989). Frankenstein. New York: UP

\begin{tabular}{|l|l|}
\hline CC) 2017 by the author. Licensee University of Chitral, Journal of Linguistics \& \\
Literature, Pakistan. This article is an open access article distributed under the \\
terms and conditions of the Creative Commons Attribution (CC BY) \\
(http://creativecommons.org/licenses/by/4.0/).
\end{tabular}

